\title{
ЦИТОТОКСИЧЕСКАЯ АКТИВНОСТЬ КОМПЛЕКСОВ ПАЛЛАДИЯ С ТЕРПЕНОВЫМИ ЛИГАНДАМИ
}

\author{
Я.А. Гурьева', О.А. Залевская' , А.В. Кучин', Ю.Р. Александрова², \\ М.Е. Неганова ${ }^{2}$ \\ ${ }^{1}$ Институт химии ФИЦ Коми НЦ УрО РАН, \\ 167000, Россия, Сыктывкар, ул. Первомайская, д.48. \\ ${ }^{2}$ ИФАВ РАН, 142432, Московская обл., Черноголовка, Северный проезд, д. 1.
}

DOI: 10.19163/MedChemRussia2021-2021-274

E-mail: gurjeva-ja@chemi.komisc.ru

В настоящее время металлокомплексные соединения уже нашли эффективное применение в клинической практике в качестве противоопухолевых препаратов [1]. Комплексы палладия с различными органическими лигандами активно исследуются в этом направлении [2]. Нами выполнены исследования цитотоксической активности ранее описанных и новых комплексов палладия различного типа, содержащих терпеновые лиганды. Определение цитотоксического профиля проводили на ряде клеточных линий опухолевого происхождения - $\mathrm{A} 549, \mathrm{SH}-$ SY5Y, Hep-2, Hela, и на клетках нормального происхождения - эмбриональной почки человека (Hek-293).

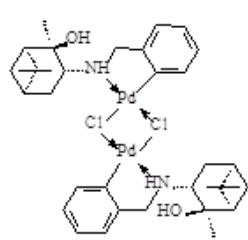

1

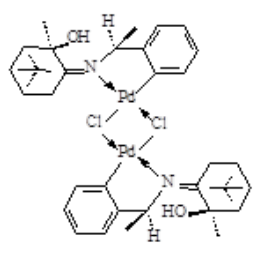

2

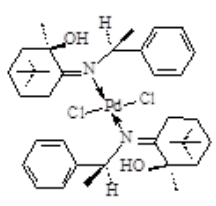

3

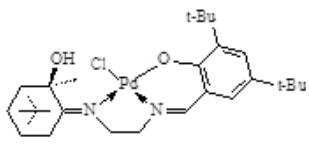

4

Установлено, что наиболее выраженными противоопухолевыми свойствами обладают комплексы палладия с терпеновыми производными бензиламина (1-3) и палладокомплекс саленового типа (4). Наибольшей цитотоксичностью обладало соединение 4, для которого на клетках нейробластомы SH-SY5Y величина IC составляла меньше 0,1 мкМ. В ходе изучения возможных механизмов их антинеопластического действия было обнаружено, что данные вещества способны модулировать функциональные характеристики митохондрий, запуская процесс «набухания» органелл и оказывая деполяризующее действие на митохондриальную мембрану, а также ингибировать процесс гликолиза в клетках опухолевого происхождения HeLa.

Исследование выполнено при финансовой поддержке РФФИ в рамках научного проекта № 20-03-00027.

\section{Литература}

[1] S. Medici, M. Peana, V.M. Nurchi et al., Coord. Chem. Rev. 2015, 284, 329-350.

[2] J. Pengpeng, O. Ruizhuo, C. Penghui et al., J. Coord. Chem. 2017, 70, 2175-2201. 